RJOAS, 8(80), August 2018

DOI https://doi.org/10.18551/rjoas.2018-08.17

\title{
THE ROLE OF SERVICE EMPATHIZE TOWARDS PUBLIC SATISFACTION: A CASE STUDY AT POPULATION AND CIVIL REGISTRATION AGENT OF SOUTH CENTRAL TIMOR REGENCY
}

\author{
Kamlasi Yusri D. \\ Postgraduate School, University of Airlangga, Indonesia \\ E-mail: yusrikamlasi@gmail.com
}

\begin{abstract}
The research aims to understand the role of empathy dimensions towards the public satisfaction to the service of Population and Civil Service Agent of South Central Timor Regency. The large number of complaints against the service quality is the reason for this research. To find out the cause of the importance of service empathize by the apparatus, it is necessary to understand the public complaints about the quality services they received, especially in the dimension of empathy. The research method used is descriptive qualitative. The results of the study prove that services empathize by apparatus is essential for the satisfaction of the community towards public service. The high expectations of the community to empathetic services of apparatus caused by cultural factor, psychological and social status.
\end{abstract}

\section{KEY WORDS}

Empathy, public service, satisfaction, service quality.

One of the indicators of community satisfaction towards the services received is full service attention to consumer (empathy). In accordance with the basic principles of good governance that is the realization of a democratic services, any bureaucratic actors need to uphold humanitarian principles and moral values. Public satisfaction to the public service in Indonesia has always been an important issue to be discussed. It is inseparable from the work behavior of the bureaucracy that has been getting low ratings from the public. The problems that occurred in The Population and Civil Registration agent of South Central Timor Regency is the public dissatisfaction to the service of the apparatus.

Some research proved that the satisfaction of the public focus more on elements of service of process. The research conducted by Fahmi Reza (2016) on the influence of the quality of public services against the public satisfaction. The indicators used are tangible, responsiveness, assurance, and empathy. The results showed a significant influence. .Furthermore, a study conducted by Muhsin and Ikhsani (2017), there is a simultaneous influence on dimensions of empathy towards the public satisfaction. Mentioned that the influence simultaneously between the empathy of employees to public satisfaction reached $61.3 \%$. Based on the results of this study, we can see that empaty is very influential on service quality.

To measure quality of service an organization, cannot be done simply by using a single indicator, but to improve the quality of service, it can be done by a specific dimension on a priority. Such as research conducted by Khanifatul Khusna (2017) by focusing on dimensions of empathy with indicators understanding the community, service orientation, developing others and capitalize on its diversity.

Each community with geographical conditions and different cultures will certainly give a different assessment to the same social problem. In contrast to research conducted by Khanifatul Khusna, this research will be focused on public service quality dimensions of empathy. Formulation of the problem in this research is how complaints against the public service in the Office of the Population and civil registration agent of South Central Timor 
Regency, and what are the factors that lead to high complaints on dimensions of empathy. Therefore, the researcher tried to find the extent of apparatus empathy in serving the community. The reason of focusing this study on dimensions of empathy is based on the results of pra research conducted on October 12 to October 19, 2017 at the offices of the population and civil registration agent of South Central Timor Regency, there were many complains by the community about apparatus behavior that is considered not understand the needs and expectations of society as the customer.

If the previous studies have attempted to find the drivers and inhibiting factors of service empathized by apparatus, this research will try to find the factors that cause the service empathize is important for the satisfaction of public to the service quality. The importance of the dimensions of empathy in this research is seen from the community viewpoint, so the purpose is to describe the role dimensions of empathy for the public satisfaction to the service of apparatus in the Office The population and Civil registration agent of South Central Timor Regency.

\section{LITERATURE REVIEW}

The satisfaction of the community largely determine the success rate of the public service of a government agency. This problem requires major attention from the service provider. Service providers in the public service is the Government apparatus who providing services in accordance with the legislation. While the public as consumers or recipients of services are people, communities or institutions who benefit from a public service activities.

There are five dimensions of service quality according to Zeithaml, et al (1990):

- Reliebility is the ability of the apparatus to provide accurate, credible, on time, and avoid repeating the mistake;

- Responsiveness is the willingness of the apparatus to provides services depending on the public expectations;

- Assurance; including knowledge, ability, friendly, courteous and trustworthy;

- Empathy is the ability to understand both the needs and the difficulty of consumers including good communication, personal attention and ease in doing communications;

- Tangible; including the availability of physical facilities and equipment.

This research is focused on dimensions of empathy. Empathy possessed by any public servant will establish a good system of service. Empathy is used in assessing the quality of public services in order to find all the requirements desired by the consumer. Howe (2005), said that empathy is the ability to identify what is in others mind, so we can appropriately respond to their thoughts and feelings.

Empathy is the basic ability to understand social skills at work. These skills according to Goleman (2003) are understanding others, serving orientation, developing others and appreciating diversity. In this study, the indicators used are understanding others and service orientation. Understanding others according to Goleman (2003) consists of the ability to pay attention and listen properly, showed sensitivity to other people's perspective, and understand the needs of others. While the service orientation consists of understand and adjust the service to the public needs, try a variety of ways to give satisfaction towards the services and act as a trusted advisor.

According to Sciffman and Kanuk (2008), customer behavior is a process of searching, using, evaluating and acting in consuming products or services that are expected to meet the needs of the person. Furthermore, Kotler (2008) suggests factors that affect customer behavior that is culture, social status, personal and psychological. The behavioral indicators used in this study are cultural, social status and psychological. Culture is the determinant of the desire and the most basic constituent of behavior. Each culture is composed of sub-culture that is more revealing identification and socialization for its members. social status is also one of the factors 
that can influence customer behavior. A person with higher social status will have an effect on the attitude and sense of high esteem in the community. Another factor is psycological. Psychological factors are more focussed on the public perception and motivation.

\section{METHODS OF RESEARCH}

The approach used in this research is descriptive qualitative approach. This research was conducted at the offices of The population and Civil Registration Agent of South Central Timor Regency. Informants in this study were five persons selected randomly to the community who have repeatedly received service at the Office of Population and Civil Registration agent of South Central Timor Regency.

\section{RESULTS AND DISCUSSION}

Based on regional regulation No. 13, 2011 as the changes of regulation No. 21, 2007 about organization and functioning of regional technical agencies, The Population and Civil Registration Agent of South Central Timor Regency is a unit of Local Government Agency (called SKPD) is responsible for planning, developing, controling, and evaluation based on the local governments authority in the field of the administration of population and civil registration.

Distribution of the population in South Central Timor Regency generally uneven. This is due to the geographical and natural environmental condition. Based on the registration of inhabitant in 2016, the population of South Central Timor Regency amounted to 456,152 inhabitants. The area of South Central Timor Regency is $3947 \mathrm{~km}^{2}$. There are 32 sub-districts administration consisting of 240 villages. The population administration services is centered in the office of the population and civil registration agent .

Population administration services in the district of South Central Timor as a whole are served in the Office of Population and Civil Registration Agent located at the capital city of the regency, while the number of human resources owned only amounted to 32 people. It can be concluded that with a small number of employees and a large service area, sufficient empathy is required by the apparatus in serving the community.

To assess the empathy of the apparatus in an institution, it is necessary to understand the community as an object of service. Based on the observation and interviews, apparatus are considered not able to provide services that empathize to the community. The measured indicator is the ability of appartus to understand the community. This is in accordance with the statement in the pass by MYA (informant) that:

"To be able to get here (Office of Population and Civil Regidtration Agent of South Central Timor Regency) from the village, requires effort and expense. Our hope is to get priority service from the apparatus, including friendly service and ease of service. But that was not happened, when you make a little mistake then they will ask you to go back to fix it which of course will take time and cost "

Based on the above statement, then it can be said that apparatus still have not understand the community. The community expectation to have full empathy by apparatus of The Population and Registration agent of South Central Timor Regency was not seen in terms of understanding others.

Another indicator of empathy is service orientation. The description of service orientation at The Population and Civil Registration Agent of South Central Timor regency is to provide services and fulfill every interest of the community as the recipient of the service. The motto was used in the service is to provide a friendly service and oriented to the satisfaction of the community. An informant initials ON who asked about the motto, he said that:

"Talking about friendly, I don't want to say that the apparatus is not friendly but with the large number of people queuing to get service here everyday, the hospitality of the officers does 
not seem to be a priority. Then if they say that service is oriented to the public satisfaction, I see it is still not so obvious, because if we want to ask about the requirements, the officer will reason that there are still many people who queue, don't take to much time to ask ".

Some informants also said that friendly service here is still considered poorly when compared with services obtained at other agencies. In addition, service delay is one indicator of public complaints towards service orientation. Apparatus are considered insensitive to the public needs. An informant says that:

"The Service here is still hard to be on time, they promise to be completed within three days but sometimes we have to wait for months. So, the villagers must repeatedly waste time and money for just one document ".

The above statements show the public's complaints about services that are felt not empathetic. So, researcher will try to find the causes why people want empathetic service.

The reason the public want empathetic service is measured based on customer behavior toward a service product which indicator consist of cultural factor, social status, personal and psychological.

Based on the observation and interviews, people in South Central Timor Regency still upholding the values of local culture. Local cultural values that are used in this research is a moral value. Moral values are largely determined by the attitudes, behavior and speech of someone in interacting with others. Interview conducted against YA (speaker) says that:

"At a time when our name was called to get service, surely we will greet to the apparatus, but they rarely answered. They direct ask, what do you want to do? the question of apparatus like we are in the investigation of a crime case. Even once there was a village chief who was shouted by the officer, although it was not appropriate for a village head to be shouted like that "

The above statement is very clear that moral values are very important for society, especially in rural communities. Attitudes of the apparatus are considered incompatible with moral values held by society, where a leader must be respected and treated well.

The other indicator in the role of empathy is social status. Social status is the position of a person in a hierarchical order in society. A person with a high social status within a particular group of people will be treated differently from that member of the community. Based on observations, people who want to get service come from different backgrounds. Those who have high positions in the community always want to be prioritized even though the Department of Population and Civil Registration of Timor Tengah Selatan district has its own mechanism and service procedure. TA, one of the interviewees said that he did not want to jostle to register a name because he thought it was very disrespectful to the public. After further questioning by the researcher, it turns out that the source is a highly respected public figure in his village. This is certainly one of the reasons that it desperately needs the special attention of the apparatus whose desirability is already contrary to the principle of equity.

Another factor that also affects the public expectation of empathetic service is psychological factor. Psychological factors can be measured based on public perceptions or motivations. Perception is a process done to select and organize the information obtained, while motivation is a drive that requires a person to do something. Based on the results of interviews conducted on a person with the initials $A B$, he said that:

"The services we get here from past until now never changes. All those who came here will definitely go home with the same story like the rude service and did not allowed us to ask question "

The above statement can be concluded that the perception conveyed by the informant is the result of experience and information that he got. However, based on observations, apparatus was not always rude to the public, the attitude and appearance of the people that was the reason why the apparatus became abusive, such as people who comes by using impolite dress or dishonest about the previous identity. The motivation of the community to complete the document of population administration is also one of the reasons for the people to get 
empathetic service. Based on the interviews, public have less awareness to the completeness of the document of population adminisatration. ON (informant), said that:

"If it were not for my children's schooling, maybe I never came here to make ID cards or anything else"

This statement indicates that the motivation of the community to complete the document of population administration is due to the demands of the child's schooling needs. So this makes them sensitive to the service received. Few mistakes made by the apparatus will be considered unworthy by the community.

\section{CONCLUSION}

According to the analysis, It can be concluded that the dimension of empathy in Population and Civil Registration Agent of South Central Timor regency services tend to be considered negative by society. People complain about apparatus behavior that do not understand their needs and expectation. Public expectation for the empathetic service is quite high. It is caused by cultural factors, social status and psychological.

\section{ACKNOWLEDGEMENTS}

The author would like to thank to Prof. DR. Budi Prasteyo, Drs, M.Si as the supervisor for this research.

\section{REFERENCES}

1. Goleman, Daniel. 2003. Kecerdasan emosi untuk mencapai puncak prestasi. Yogyakarta: PT Gramedia Pustaka Utama.

2. Howe, David. 2005. Empati, makna dan pentingnya. Ahli Bahasa: Ahmad Lintang Lazuardi, Yogyakarta: Pustaka Pelajar.

3. Ikhsani, A. F. \& Muhsin. 2017. Penngaruh Komunikasi Non Formal, Disiplin Kerja, Kompetensi Pegawai dan Empati Pegawai Tata Usaha terhadap Pelayanan Siswa SMK Palebon Semarang. Economic Education Analysis Journal, 6(1), 83-95.

4. Kotler \& Amstrong. 2008. Prinsip-prinsip Pemasaran. Jilid 1 \& 2, edisi 12. Jakarta: Erlangga

5. Kusna, Khanifatul. 2017. Pengembangan Dimensi Empati sebagai Upaya Peningkatan Kualitas Pelayanan Publik di Kantor Kecamatan Gubeng Surabaya. Skripsi: ITS Surabaya

6. Schiffman \& Kanuk. 2008. Perilaku konsumen. Edisi 7. Jakarta: IndeksZeithaml V. et al. 1990. Delivering Quality. $5^{\text {th }}$ Edition. Free Press.

7. Zulfikar, Fahmi R. 2016. Pengaruh Persepsi Kulaitas Produk, Kesadaran Merek, Fitur Program dan Harga, terhadap keputusan pembelian Ponsel Xiaomi di Surabaya. STIE Surabaya: Perbanas International Repository. 